\title{
Pyroelectrically generated very low dose ionizing radiation enhances chemopreventive and chemotherapeutic effects of Genistein isoflavone in human prostate cancer cells
}

\begin{abstract}
An estimated 233,000 American men will be diagnosed with new cases of prostate cancer with 29,480 men expected to die from the disease in 2014 . These statistics will regrettably add to the burden of about 2,617,682 men currently living with the disease in the United States. The development of resistance by cancer cells to radiation and chemotherapy has limited the efficacy of the current therapeutic interventions, thereby informing the need for a novel effective and safer alternative therapeutic regimen. In this study, we exploited the role of low dose Hyperradiosensitivity (LD-HRS) in enhancing the chemopreventive and chemotherapeutic effects of Genistein by pretreatment exposure to very low dose ionizing radiation (VLDR, 20mGy/hr) using a Pyroelectrically generated X-ray source (non-radioactive) in two human prostate cancer cell lines in vitro. The presence of HRS was assessed using the MTT assay. Treatment-induced intracellular levels of ROS and SOD were assessed using Nitro blue tetrazolium assay. Adaptive response mediated by VLDR following delayed drug treatments was also investigated and found to be both time-dependent and dose-dependent in $\mathrm{LNCaP}$ cell line. $\mathrm{LNCaP}$ cells were found to be slightly more radiosensitive compared to PC3 cells after exposure to $20 \mathrm{mGy} / \mathrm{hr}$ VLDR. Both cell lines were found to induce some form of HRS. VLDR alone or in combination with a low dose of Genistein $(10 \mu \mathrm{M})$ was found to proffer the highest treatment induced chemoprevention by elevating the levels of cellular anti-oxidant enzymes (SOD). High doses of Genistein increased intracellular levels of ROS and growth inhibition, thereby, favoring the chemotherapeutic effects of Genistein. In all treatment groups, apoptosis tends to be the most common mechanism of cell death. These findings indicate that chemo enhancement by VLDR can be associated with modulation of the percentage cell survival rate (CSR), apoptosis, HRS, and SOD or ROS levels in prostate cancer cells.
\end{abstract}

Keywords: prostate cancer, low dose hyperradiosensitivity (ld-hrs), apoptosis, Genistein, pyroelectricity, ROS, SOD
Volume I Issue 2 - 2014

\author{
Saheed Oluwasina Oseni, 1,3 James Kumi- \\ Diaka,' Rolando Branly, ${ }^{2}$ Joubin Jebelli, \\ Jessica Warrick,' Harris Goldsmith' \\ 'Department of Biological Sciences, Florida Atlantic University, \\ USA \\ 'Department of Physical Sciences, Broward College, USA \\ ${ }^{3}$ Department of Veterinary Microbiology and Parasitology, \\ Federal University of Agriculture, Nigeria
}

Correspondence: James Kumi-Diaka, Department of Biological Sciences, Florida Atlantic University, USA, Tel 954-236I 135,Email jdiaka@fau.edu

Received: August 23, 2014 | Published: September 30, 2014
Abbreviations: LD-HRS, low dose hyper radio sensitivity; ROS, reactive oxygen species; SOD, superoxide dismutase; DGIR, differential growth inhibition rate; GER, Genistein enhancement ratio; $\mathrm{X} 20 \mathrm{mGy} / \mathrm{hr}$, $\mathrm{x}$-ray at $\mathrm{x} 20 \mathrm{mgy} / \mathrm{hr}$ dose; VLDR, very low dose radiation; MTT, (3-4,5-dimethylthiazolyl-2-2, 5-diphenyletrazolium bromide assay; CSR, cell survival rate; NBT, nitro blue tetrazolium assay; $\mathrm{AO} / \mathrm{EB}$, acridine orange/ ethidium bromide; ARR, adaptive response rate

\section{Introduction}

Prostate cancer remains the most common form of non-cutaneous cancers and the second leading cause of cancer death in American men, apart from lung cancer, ${ }^{1}$ thus accounting for $27 \%$ of all new cases of cancer and $10 \%$ of estimated deaths. An estimated 233,000 men will be diagnosed with new cases of prostate cancer and an estimated 29,480 deaths are expected in $2014 .^{2}$ These statistics will regrettably add to the burden of about 2,617,682 men currently living with the disease in the United States. ${ }^{1}$

Conventional therapies for localized prostate cancer such as radical prostatectomy, androgen deprivation therapy, chemotherapy or radiotherapy are not always curative, with more than $20 \%$ of the patients exhibiting biochemical recurrence after 10years, ${ }^{3}$ due to moderate to severe long-term side effects from treatment-induced cytotoxicity to normal tissues. ${ }^{4}$ These treatment-induced side effects could result in advanced or metastatic form of the cancer, with consequent fatalities. ${ }^{5}$ Development of resistance by cancer cells to radiation- and chemo-therapy also limits the efficacy of these therapeutic interventions. ${ }^{6}$ It would therefore be strategic to develop novel alternative therapeutic regimens that are minimally cytotoxic to normal tissues and effective against prostate cancer. ${ }^{7}$

Many epidemiological and experimental studies have documented the modulatory effects of dietary or phytochemical agents in the carcinogenesis of prostate cancer. ${ }^{8-11}$ Genistein Isoflavone (4', 5', 7'-trihydroxyisoflavone) is one of the most widely studied potent phytochemical compounds that exhibit anti-cancer activities., ${ }^{72}$ Genistein is a dietary flavonoid (polyphenol) extracted from soy in soybeans and can also be found in lentils as well as some fruits and vegetables. ${ }^{13}$ This phytoestrogen has been reported to induce cytotoxicity, inhibit cellular proliferation, and promote apoptotic cell death in various cancer cells in vivo and in vitro. ${ }^{14,15}$

The anti-cancer effects of Genistein has been demonstrated in breast, lung, prostate, lymphoma, leukemia, and head and neck cancers $^{14-23}$ via many mechanisms that include: inhibition of topoisomerase I \&amp; II, ${ }^{18}$ inhibition of telomerase activity, ${ }^{24}$ 
inhibition of tyrosine kinase signaling pathway, inhibition of two cell survival proteins; Akt and NF-k $\beta^{25}$ and two anti-apoptotic proteins; $\mathrm{Bcl}-2$ and $\mathrm{Bcl}-\mathrm{XL} \cdot{ }^{20,26,23}$ The up regulation of the pro-apoptotic proteins; Bax and $\mathrm{Bad}^{14,20,27,28}$ and a decrease in vascular epithelium growth factor (VEGF) correlating with a reduction in angiogenesis has also been reported. At low concentrations, Genistein behaves as an antioxidant and at high concentration, Genistein operates as a prooxidant. High concentrations of Genistein create an increase in ROS production, which potentially leads to DNA damage and cell arrest at the $\mathrm{G} 2 / \mathrm{M}$ cell cycle phase. ${ }^{16,29}$

According to the BEIR VII report, low doses of radiation is defined as radiation that does not exceed $100 \mathrm{mSv}(100 \mathrm{mGy}){ }^{30,31}$ Dual responses have been described in most mammalian cells when exposed to low doses of ionizing radiation. ${ }^{32,33}$ The first response prevents and repairs DNA damage which keeps cells viable and functioning properly. The second response removes damaged cells by inducing apoptosis, terminal differentiation, and immune responses, thus eliminating mutated cells and reducing genomic instability in exposed tissues..$^{34,35}$

Unlike the high power sources of X-ray radiation-linear accelerators and synchrotrons-used currently for radiotherapy, ${ }^{36}$ recent investigations have focused on the development of novel and cheaper low power milli/micro/nano X-ray sources for low dose irradiation. ${ }^{37,38}$ These technologies are developed with the intention of utilizing the theories from physical phenomena such as pyroelectric, piezoelectric, and triboelectric effects for compact high-voltage beam acceleration and X-ray generation, sufficient enough to substitute the traditional high power sources..$^{39-42}$ One of the newly developed inventions in the field of nuclear physics is the pyroelectric X-ray generator, which is based on the use of pyroelectric crystals to generate $\mathrm{X}$-ray radiations from a non-radioactive element. The technological development of pyroelectric X-ray generators has enabled physicists and radiologists to develop ultra-portable, low-power X-ray sources useful in imaging, crystallography, material analysis, and other applications. ${ }^{43-44}$

The major goals of combined treatment protocols are to improve the local control and prevention of distant micro metastases, which may be floored by the intrinsic radio resistant and chemo resistant properties of most solid tumors. ${ }^{45}$ Findings from some studies have suggested that many cancer cells are sensitive to low doses or fractionated doses of radiation, and that (very) low doses of radiation can be used to enhance or potentiate the chemotherapeutic effect of most drugs, while at the same time decreasing the development of resistance by tumors. ${ }^{46}$ At low or very low doses of radiation, HRS has been demonstrated to be responsible for the increased sensitivity observed in these cells at doses less than $0.3 \mathrm{~Gy} .{ }^{47,48}$

Synergistic and/or additive combinations of phytochemical compounds and low or very low doses of radiation offer favorable outcomes, such as increasing the efficacy of therapeutic effects by avoiding toxicity to normal cells, decreasing the dosage and preventing development of chemo-resistance or radio-resistance. ${ }^{49}$ However to take advantage of the benefits of LD-HRS in the clinical setting, therapy would have to be extended over 7-12 weeks, allowing tumor survival and repopulation that could abolish the gain attributable to enhanced cell killing. ${ }^{50}$ Therefore, the need to develop an alternative way to maximize this enhanced cell killing at low doses of radiation would be through combination treatment modalities as demonstrated in the present study.

The current study was therefore designed to explore and exploit the enhanced cell killing and/or growth inhibition with a combination of Genistein Isoflavone and low doses of radiation in the form of HRS. The study investigated the potential benefits of Genistein potentiation or enhancement by very low dose radiation (VLDR) pre-treatment exposures. The roles of low dose Hyperradiosensitivity (LD-HRS), reactive oxygen species (ROS) modulation and induction of adaptive responses in determining cellular response and mode of cell killing were also investigated. Our findings demonstrate that potential chemotherapeutic/chemopreventive enhancement by VLDR may be associated with the intrinsic radiosensitivity of individual cell lines rather than the HRS phenomenon alone. The study also indicates that the mode of cell killing in low dose exposure to radiation and Genistein combination may be by growth inhibition and/or apoptosis. Evidently, this combination treatment modality could be of clinical importance; and therefore justifies further in-depth studies.

\section{Materials and methods}

\section{Reagents and phytochemical}

Genistein (4', 5, 7- trihydroisoflavone) (Indoline Chemical Co., Summerville, NJ, U.S.A.) was dissolved in DMSO (DimethylSulfoxide) obtain a $100 \mu \mathrm{M}$ stock solution. The final concentration of solvent did not exceed $0.5 \%$. Previous studies showed that up to $1 \%$ DMSO solvent in the final sample did not alter the assay result. ${ }^{12}$ Stock solution was further diluted with RPMI-media to produce aliquots in concentrations of $0,10,20,30,50$ and $70 \mu \mathrm{M}$ $\left(G_{0}-G_{70}\right)$ based on previous studies. ${ }^{7}$ They were frozen and stored at $-37^{\circ} \mathrm{C}$ until needed.

\section{Cell cultures and culture conditions}

Cell lines were incubated at $37^{\circ} \mathrm{C}$ and $5 \% \mathrm{CO}_{2}$ for $24-96$ hours depending on individual cell doubling time. Both human prostate cancer cell lines (LNCaP and PC3) were obtained from the American Type Culture Collection (Manassas, VA). All the cell lines were grown in RPMI 1640 containing 15mM HEPES and maintained as monolayers in $25 \mathrm{~m}^{2}$ tissue culture flasks (Sigma Scientific, St. Louis, MO, USA). They were supplemented with $100 \mathrm{U} / \mathrm{ml}$ penicillin, $100 \mu \mathrm{g} /$ $\mathrm{ml}$ streptomycin, $10 \%$ fetal bovine serum, and $100 \mu \mathrm{g} / \mathrm{ml} \mathrm{L}$-glutamine (Sigma Scientific, St. Louis, MO, USA).

\section{In vitro pyroelectric $\mathbf{X}$-ray irradiation}

Each prostate cancer cell line was maintained as a monolayer in $25 \mathrm{~cm}^{2}$ plastic flasks following initial culture to $70-80 \%$ confluence, and were thereafter seeded $\left(1 \times 10^{4}\right.$ cells per well $)$ in micro plates. All irradiations were performed using a miniaturized portable pyroelectric $\mathrm{X}$-ray generator (Cool X, AMPTEK INC, Bedford, MA) based on the principle of Pyroelectricity. The generator utilizes a pyroelectric crystal to generate energetic electrons that produce X-rays in the target material $(\mathrm{Cu})$, when crystal is thermally cycled (without the use of radioisotopes or high power X-ray tubes). It is thermally cycled between 2 to 5 minutes, and hence, does not produce a constant flux of X-rays. Cells were irradiated with exposure to single doses of very low dose ionizing radiation (VLDR) at $20 \mathrm{mGy} /$ hour (i.e. $0.3 \mathrm{mGy} / \mathrm{min}$ dose rate) low LET $\mathrm{X}$-ray radiation. The $\mathrm{X}$-ray generator operates at $35 \mathrm{kV}$. A customized X-ray proof Lead Box was designed for this purpose. Geiger counter (SPETECH, USA) was used to monitor ionizing radiation risk in the lab and in the X-ray box. In order to maintain, a suitable humidified atmosphere within the box $(5 \%$ $\mathrm{CO}_{2}$ and $37^{\circ} \mathrm{C}$ ), the X-ray box was padded with BD GasPakTM EZ Anaerobe Container system with indicator maintained at $37^{\circ} \mathrm{C}$ and $5 \% \mathrm{CO}_{2}$ within the box. 


\section{MTT assay}

To determine the anti-proliferative or growth inhibitory effects of VLDR and/or Genistein treatments on each prostate cancer cell line, MTT assay was used. MTT (3-4, 5-dimethylthiazolyl-2-2, 5-diphenyltetrazolium bromide) is a tetrazolium dye used to determine percentage cell survival rate $(\% \mathrm{CSR})$ or differential growth inhibition rate (DGIR), which is equivalent to HRS in this study. The MTT dye detects metabolic activity through preferential conversion of viable cells into purple colored formazan. The enzyme mitochondria dehydrogenase is only present in the active mitochondria of living cells, and is responsible for cleaving the tetrazolium substrate into insoluble formazan. The color intensity generated is directly proportional to the number of viable (metabolically active cells) and quantitatively determined by optical absorbance from individual wells

Briefly, LNCaP and PC3 cells were plated onto 96 well plate each at a density of $1 \times 10^{4}$ cells per well. They were primed with single doses of $20 \mathrm{mGy} /$ hour ionizing radiation (VLDR) from a pyroelectric $\mathrm{X}$-ray generator and then incubated with graded doses of Genistein $\left(\mathrm{Gn}_{0-70}\right)$ for 24hours. Cells were treated with Genistein, 4hours after irradiation for most experiments. $100 \mu \mathrm{L}$ of MTT $(2.5 \mathrm{mg} / \mathrm{ml}$ in PBSphosphate buffered saline) (Sigma Scientific Chemical Co., St Louis, MO, USA) solution was added to each well and incubated for 4 hours at $37^{\circ} \mathrm{C}$ and $5 \% \mathrm{CO}_{2}$ to allow for the reduction of MTT into formazan by viable cells. The insoluble formazan crystals formed were solubilized or lysed to release the formazan product by adding $100 \mu \mathrm{L}$ of lysing solution (DMSO) to each pellet. Cells from each well were harvested (by vigorous aspiration with the micropipette), transferred to a labeled micro centrifuge tube and centrifuged for 10 minutes at 5000rpm. Any unincorporated MTT dye was removed by discarding the supernatant. The contents of each tube were transferred into different wells of a 96well micro titer plate. The absorbance values were measured at $490 \mathrm{~nm}$ with an automated micro plate reader (BioTek, Vermont, USA). The relative population of live cells could therefore be determined based on the optical absorbance (optical density, OD) of the sample. The values of the blank wells were subtracted from each well of treated and control cells; and the mean percentage of post-treatment viable cells relative to the controls was calculated as shown:

$$
\% \text { Cell Survival Rate }(C S R)=\frac{\left(A_{T}-A_{B}\right)}{\left(A_{C}-A_{B}\right)} \times 100
$$

Where $A_{C}$ is the absorbance of the control (mean value), $A_{T}$ is the absorbance of the treated cells (mean value), and $A_{B}$ is the absorbance of the blank (mean value).

Genistein enhancement ratio (GER) by very low dose radiation was calculated using the following formula based on percentage cell survival rate $(\% \mathrm{CSR})$;

$$
G E R=\frac{\% C S R(G n)}{\% C S R\left(\operatorname{VLDR}\left(\frac{20 m G y}{h r}\right)+G n\right)}
$$

Treatment-induced differential growth inhibition rate (DGIR) between the single and combination treatments with Genistein alone and Genistein with VLDR was calculated also using the formula based on difference in \% CSR.DGIR is equivalent to the HRS.

$$
\operatorname{DGIR}(H R S)=\% \operatorname{CSR}(G n)-\% \operatorname{CSR}\left(\operatorname{VLDR}\left(\frac{20 m G y}{h r}\right)+G n\right)
$$

For histomorphological studies, the various cells were treated as described, and micro photographed directly under inverted microscope using a digital camera (Nikon: Coolpix VR \& ISO 2000, Japan).

\section{Evaluation of adaptive response (AR) phenomenon in LNCaP cell line}

To test for treatment-induced adaptive response in LNCaP cells; the same procedure was followed as described above, but in this experiment, intervals of 4hours and 24 hours were created between exposure to VLDR and treatment with graded concentrations or doses of Genistein $\left(\mathrm{Gn}_{0-70}\right)$ and thereafter incubated for 24 hours at $37^{\circ} \mathrm{C}$ and $5 \% \mathrm{CO}_{2}$. The percentage cell survival rates (\% CSRs) were calculated relative to the controls to determine the HRS, which was each (y-axis) plotted against the graded concentrations of the drug (along $\mathrm{x}$-axis).

Differential growth inhibition rate (related to adaptive response) (DGIR) by very low dose radiation (VLDR) at $4 \mathrm{hrs}$ and $24 \mathrm{hrs}$ drug treatment intervals was calculated using the following formula based on percentage cell survival rate (\% CSR);

$$
D G I R_{A R}\left(H R S_{A R}\right)=\% C S R\left(V L D R\left(\frac{20 m G y}{h r}\right)+G n\right) \wedge 4 h r s-\% \operatorname{CSR}\left(V L D R\left(\frac{20 m G y}{h r}\right)+G n\right) \wedge 24 h r s
$$

Genistein enhancement ratio (related to adaptive response) $\left(\mathrm{GER}_{\mathrm{AR}}\right)$ by very low dose radiation (VLDR) at $4 \mathrm{hrs}$ and $24 \mathrm{hrs}$ drug treatment intervals was calculated using the following formula based on percentage cell survival rate (\% CSR);

$$
G E R_{A R}=\frac{\% C S R\left(\operatorname{VLDR}\left(\frac{20 m G y}{h r}\right)+G n\right) \wedge 4 h r s}{\% C S R\left(V L D R\left(\frac{20 m G y}{h r}\right)+G n\right) \wedge 24 h r s}
$$

Adaptive response ratio (ARR) by very low dose radiation (VLDR) at $4 \mathrm{hrs}$ and $24 \mathrm{hrs}$ drug treatments intervals was calculated using the following formula based on percentage cell survival rate (\% CSR);

$$
A R R=\frac{\% C S R\left(V L D R\left(\frac{20 m G y}{h r}\right)+G n\right) \wedge 24 h r s}{\% C S R\left(V L D R\left(\frac{20 m G y}{h r}\right)+G n\right) \wedge 4 h r s}
$$

\section{Nitro blue tetrazolium-reactive oxygen species assay}

Cells have a variety of defense mechanisms to ameliorate the harmful effects of reactive oxygen species (ROS). Superoxide dismutase (SOD) catalyzes the dismutation of the superoxide radical $\left(\mathrm{O}_{2}-\right)$ into hydrogen peroxide $\left(\mathrm{H}_{2} \mathrm{O}_{2}\right)$ and elemental oxygen $\left(\mathrm{O}_{2}\right)$, while the catalase and peroxidases convert $\mathrm{H}_{2} \mathrm{O}_{2}$ to water and as such is one of the most important antioxidative enzymes that provides important defense against the toxicity of the superoxide radicals..$^{51,52}$ In this assay, superoxide ions $\left(\mathrm{O}_{2}^{-}\right)$and/or hydrogen peroxides generated by $\mathrm{X}$-rays and/or graded Genistein treatments reduce or convert NBT to NBT diformazan. SOD reduces the superoxide ion concentration and thereby lowers the rate of NBT-diformazan formation. The extent of reduction in the appearance of NBT diformazan is a measure of SOD activity present in the cancer cells. Since the absorbance at $490 \mathrm{~nm}$ is proportional to the amount of superoxide anion (ROS) formed, the SOD enzyme as an inhibition activity can be quantified by measuring the decrease in the absorbance at $490 \mathrm{~nm}$, whereas an increase in absorbance (optical density) reflects an elevated level of intracellular ROS produced by the cancer cells.

Briefly, LNCaP cells were seeded at $1 \times 10^{4}$ cells per well in 96 well micro plates and allowed to attach for 24 hours at $37^{\circ} \mathrm{C}$ and $5 \%$ $\mathrm{CO}_{2}$. Relevant plates were treated as discussed previously. NBT $(1 \mathrm{mg} /$ 
$\mathrm{mL}$ ) in HBSS medium was added to the wells 24hours after treatment, and incubated for 4 hours at $37^{\circ} \mathrm{C}$ in the dark. Following incubation, cells were trypsinized and counted. Finally, samples were diluted to equal cell quantities in PBS buffer and centrifuged. Pellets collected were washed three times in DMSO, to lyse the cell membrane and the supernatant was collected. SOD/ROS production levels were quantified using an absorbance micro plate reader at $490 \mathrm{~nm}$. The results were expressed as relative percentage of SOD or ROS (SOD inhibition), normalized to unirradiated or untreated controls. Error bars represent standard deviation (SD) for three independent experiments.

\section{Cell death detection assay}

Acridine orange/Ethidium bromide fluorescence assay: The Acridine orange/Ethidium bromide fluorescence assay was used to differentiate between viable, apoptotic and necrotic cells. The two dyes function simultaneously to emit different fluorescent spectra. Acridine orange permeates both viable and non-viable cells, causing the nuclei to emit green fluorescence. The assay becomes differential with the use of Ethidium bromide, since absorption is based on the lack of cell membrane integrity; thus it selectively stains the nuclei of dead (non-viable) cells to produce red fluorescence. Cells that emit orange/brown colored fluorescence are indicative of apoptosis, while necrotic cells emit red fluorescence.

Briefly, Ethidium bromide $(25 \mu \mathrm{l})$ and Acridine orange $(75 \mu \mathrm{l})$ reagents were combined in a cocktail; of which $1 \mu \mathrm{L}$ was added to $25 \mu 1$ cell suspension, previously washed (to remove phytochemical treatment and background artifacts) and resuspended in PBS buffer $(25 \mu \mathrm{l})$. This was thereafter incubated at room temperature in a dark cabinet for 2 minutes. Next, $10 \mu$ l of cocktail was transferred onto a microscope slide, covered with a cover slip and analyzed under a fluorescent microscope with a band-pass filter. Detection of apoptosis was based on morphological and fluorescent characteristics of stained cells. Viable cells were indicated by bright green color, apoptotic cells by yellow/orange/brown, and necrotic cells by red. Cell death was quantified by counting a minimum of 50 cells in various fields per slide. For each relevant treatment regimen, fluorescence micro photographed pictures were taken directly from under the fluorescence microscope using a digital camera (Nikon: Coolpix VR \& ISO 2000, Japan).

\section{Statistical analysis}

Data were expressed as means \pm standard deviation (SD) from two different triplicate experiments to confirm similar result. The significance of the statistical difference in the means differences between various experimental and control groups was determined using student's t-test and one way ANOVA. P value of $\leq 0.05$ was considered statistically significant.

\section{Results}

\section{HRS phenomenon is present in both PC3 and LNCaP cell lines}

In order to investigate the presence of HRS and growth inhibition due to single doses of VLDR $(20 \mathrm{mGy} / \mathrm{hr})$ in both the hormone dependent $\left(\mathrm{AR}^{+}, \mathrm{P} 53^{+}\right) \mathrm{LNCaP}$ cell line and hormone independent

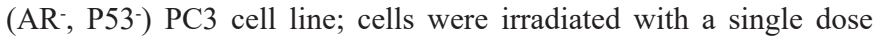
of VLDR $(20 \mathrm{mGy} / \mathrm{hr})$ from a pyroelectric X-ray source and the percentage cell survival rate (CSR) or cell viability was determined by MTT assay. (Figure 1) showed that both cell lines have some degree of HRS after exposure to VLDR. PC3 cells were found to be more radio resistant (lower HRS) to VLDR compared to LNCaP cells. A significant difference ( $\mathrm{P}<0.05$, HRS: 9.69\%) in DGIR was observed, with LNCaP cells (CSR: $77.63 \%$ HRS $_{\text {LNCaP }}$ : $22.37 \%$ ) found to be more sensitive to VLDR compared to ${ }_{\mathrm{PC} 3}$ cells (CSR: 87.32\%; $\mathrm{HRS}_{\mathrm{PC} 3}$ : $12.68 \%)$.

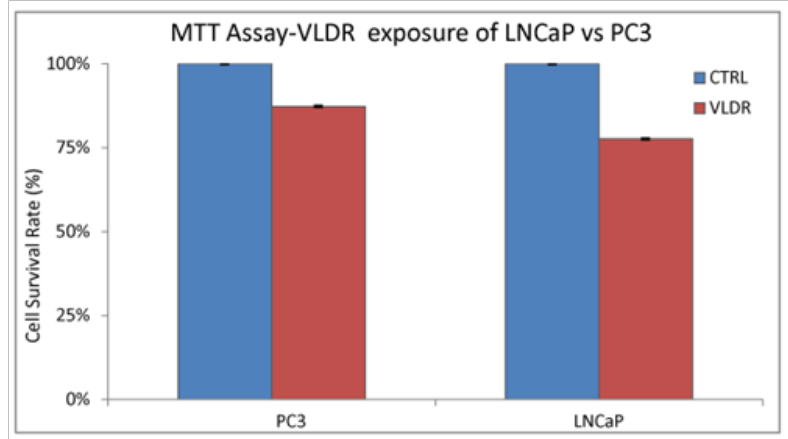

Figure I \% CSR was assessed by MTT assay in Lncap and pc3 cell lines following exposure to single doses of $\mathrm{vldr}$ at $20 \mathrm{mgy} / \mathrm{hr}$ that was pyro electrically generated as previously described in the materials and methods. The radio sensitivity of each cell line relative to the control (unirradiated cells) is indicated by the red and blue bars respectively. The cell survival rates (\%) or cell viability represent the hyper radio sensitivity (hrs) in each cell line at the exposed dose of radiation $(20 \mathrm{mgy} / \mathrm{hr})$ relative to the control. significant difference ( $p<0.05$, hrs/CSR: $9.69 \%$ ) in individual hrs was observed, with the Lncap cells (CSR: $77.63 \%$, hrs: $22.37 \%$ ) more sensitive to the VLDR compared to the pc3 cells (CSR: $87.32 \%$; hrs: $12.68 \%$ ). Data points represent the means \pm standard deviation (SD) of three independent experiments performed in triplicate. Bar $=$ SD.

Table I The DGIR (or HRS) and GER were also derived from \% CSR values from different treatment (concentration) groups

\begin{tabular}{lllllll}
\hline $\begin{array}{l}\text { CONC } \\
(\mu \mathrm{M})\end{array}$ & $\begin{array}{l}\text { Genistein } \\
(\mathbf{G n}) \text { Alone } \\
(\% \text { CSR) }\end{array}$ & $\begin{array}{l}\text { VLDR+ Gn } \\
\text { Combination } \\
(\% \text { CSR) }\end{array}$ & $\begin{array}{l}\text { Differential Growth } \\
\text { Inhibition Rate } \% \\
\text { DGIR) or (LD-HRS) }\end{array}$ & $\begin{array}{l}\text { DGIR (HRS) } \\
\text { Ranking }\end{array}$ & $\begin{array}{l}\text { Genistein Enhancement Ratio by } \\
\text { VLDR (GER) }\end{array}$ & $\begin{array}{l}\text { GER } \\
\text { Ranking }\end{array}$ \\
\hline 0 & 100 & 100 & 0 & $\mathrm{~N}$ & $\mathrm{I}$ & $\mathrm{N}$ \\
10 & 92.17 & 81.81 & 10.36 & $\mathrm{I}$ & 1.13 & 3 \\
20 & 74.03 & 68.2 & 5.83 & 5 & 1.09 & 5 \\
30 & 64.15 & 56.76 & 7.39 & 4 & 1.13 & 3 \\
50 & 51.61 & 42.35 & 9.27 & 3 & 1.22 & 2 \\
70 & 40.85 & 31.35 & 9.5 & 2 & 1.3 & 1 \\
\hline
\end{tabular}

The DGIR shows the \% change in growth inhibition between the single and combined treatment, while GER gives the ratio of single to combined treatment to assess the enhancing potential ofVLDR in Lncap cells. The ranking allows for easy assessment of dose-response based on position (increased effects). $\mathrm{N}$ (rank) = control

\%CSR, percentage cell survival rate; DIGR, differential growth inhibition rates; HRS, hyperradiosensitivity; GER, Genistein enhancement ratio; Gn, Genistein concentration;VLDR, very low dose radiation

Citation: Oseni SO, Kumi-Diaka J, Branly R, et al. Pyroelectrically generated very low dose ionizing radiation enhances chemopreventive and chemotherapeutic effects of Genistein isoflavone in human prostate cancer cells. J Cancer Prev Curr Res. 20I4; I (2):44-55. DOI: I0.I5406/jcpcr.20I4.0I.000 I0 
Table 2 The DGIR (HRS) and GER were also derived from \% CSR values from different treatment (concentration) groups

\begin{tabular}{|c|c|c|c|c|c|c|}
\hline $\begin{array}{l}\text { CONC } \\
(\mu M)\end{array}$ & $\begin{array}{l}\text { Genistein } \\
\text { (Gn) Alone } \\
\text { (\% CSR) }\end{array}$ & $\begin{array}{l}\text { VLDR+ Gn } \\
\text { Combination } \\
\text { (\% CSR) }\end{array}$ & $\begin{array}{l}\text { Differential Growth } \\
\text { Inhibition Rate (\% } \\
\text { DGIR) or (LD-HRS) }\end{array}$ & $\begin{array}{l}\text { DGIR (HRS) } \\
\text { Ranking }\end{array}$ & $\begin{array}{l}\text { Genistein Enhancement Ratio by } \\
\text { VLDR (GER) }\end{array}$ & $\begin{array}{l}\text { GER } \\
\text { Ranking }\end{array}$ \\
\hline 0 & 100 & 100 & 0 & $\mathrm{~N}$ & I & $\mathrm{N}$ \\
\hline 10 & 92.17 & 81.81 & 10.36 & I & 1.13 & 3 \\
\hline 20 & 74.03 & 68.2 & 5.83 & 5 & 1.09 & 5 \\
\hline 30 & 64.15 & 56.76 & 7.39 & 4 & 1.13 & 3 \\
\hline 50 & 51.61 & 42.35 & 9.27 & 3 & 1.22 & 2 \\
\hline 70 & 40.85 & 31.35 & 9.5 & 2 & 1.3 & I \\
\hline
\end{tabular}

The DGIR (HRS) shows the \% change in growth inhibition between the single and combined treatment, while GER gives the ratio of single to combined treatment to assess the enhancing potential of VLDR in pc3 prostate cancer cells. The ranking allows for easy assessment of dose-response based on hrs and GER. $\mathrm{n}($ rank) $=$ control.

\%CSR, percentage cell survival rate; DIGR, differential growth inhibition rates; HRS, hyperradiosensitivity; GER, Genistein enhancement tatio; Gn, Genistein concentration;VLDR, very low dose radiation.

Table 3 The ARR, DGIR ${ }_{A R}$ and GER $_{A R}$ were all derived from \% CSR all treated groups

\begin{tabular}{|c|c|c|c|c|c|c|c|c|}
\hline $\begin{array}{l}\text { CONC } \\
(\mu \mathrm{M})\end{array}$ & $\begin{array}{l}\text { VLDR+Gn } \\
@ 4 h r(\% \text { CSR) }\end{array}$ & $\begin{array}{l}\text { VLDR+Gn } \\
@ 24 h r s \text { (\% CSR) }\end{array}$ & $\begin{array}{l}\text { DGIR }_{A R} \\
\left.{\left(H_{A R}\right.}_{A R}\right)\end{array}$ & $\begin{array}{l}\text { DGIRAR } \\
\text { Ranking }\end{array}$ & $\mathbf{G E R}_{\mathrm{AR}}$ & GER $_{\mathrm{AR}}$ Ranking & ARR & ARR Ranking \\
\hline 0 & 100 & 100 & 0 & $\mathrm{~N}$ & I & $\mathrm{N}$ & I & $\mathrm{N}$ \\
\hline 10 & 81.81 & 82.72 & -0.91 & I & 0.99 & I & I.0I & 5 \\
\hline 20 & 68.2 & 71.5 & -3.3 & 2 & 0.95 & 2 & 1.05 & 4 \\
\hline 30 & 56.76 & 65.37 & $-8.6 I$ & 3 & 0.87 & 3 & 1.15 & 3 \\
\hline 50 & 42.35 & 57.89 & -15.54 & 5 & 0.73 & 4 & I.37 & 2 \\
\hline 70 & 31.35 & 44.88 & -13.53 & 4 & 0.7 & 5 & 1.43 & I \\
\hline
\end{tabular}

The ARR increased dose dependently while $G_{A R}$ decreased dose dependently. DGIR $_{A R}$ was also observed to decrease dose dependently. GER ${ }_{A R}$ and $A R R$ were observed to be inversely proportional to one another. The ranking allows for easy assessment of dose-response concentrations. $\mathrm{N}$ (Rank) = Control.

\%CSR, percentage cell survival rate; $D_{G I R}$, differential growth inhibition rates (with respect to adaptive response); HRSAR, hyperradiosensitivity (with respect to adaptive response); $\mathrm{GER}_{\mathrm{AR}}$, Genistein enhancement ratio (with respect to adaptive response); Gn, Genistein concentration;VLDR, very low dose radiation (20mgy/Hr).

\section{VLDR enhanced the effects of Genistein in both prostate cancer cell lines}

The Genistein-enhancing effects of single doses of VLDR were analyzed by MTT assay (Table 1 and 2) (Figure 1 and 2A-2D). When LNCaP cells and PC3 cells were exposed to Genistein alone, there were significant reductions (LNCaP: $\left.\mathrm{R}^{2}=0.9924, \mathrm{P}<0.05\right)(\mathrm{PC} 3$ : $\left.\mathrm{R}^{2}=0.9552, \mathrm{P}<0.05\right)$ in the \% CSR in a dose dependent manner. Significant decrease $(\mathrm{P}<0.05)$ in $\% \mathrm{CSR}$ were observed across the various treatment doses, as indicated by the red color bars in (Figure $2 \mathrm{~A}$ and $2 \mathrm{~B})$, when cells were primed with VLDR $(20 \mathrm{mGy} / \mathrm{hr})$ prior to Genistein treatment compared to when not primed. The chemopotentiating effect as seen in (Table 1 and 2), were dose-dependent and varied among different concentration in the two cell lines. The GER was highest in PC3 cells $(70 \mu \mathrm{M})$ at 1.33 and in LNCaP cells $(70 \mu \mathrm{M})$ at 1.30 . Relative disparity in \% CSR between PC3 and LNCaP cells were shown by the green and red bars in (Figure 2C and 2D). Dose-dependent significant variations $(\mathrm{P}<0.05)$ in \%CSR in both cell lines (LNCaP and PC3) were observed after 24hours of incubation with graded doses of Genistein Isoflavone $\left(\mathrm{Gn}_{0-70}\right)$. At $20 \mu \mathrm{M}, \mathrm{LNCaP}$ cells appear to be more chemo-sensitive to Genistein treatment compared to PC3 cells, whereas at $70 \mu \mathrm{M}$, the reverse occurred. Also significant difference $(\mathrm{P}<0.05)$ in dose responses at $10-30 \mu \mathrm{M}$ and $70 \mu \mathrm{M}$ between both cell lines LNCaP and PC3 were observed when cells were initially primed with VLDR prior to Genistein treatment. The results showed that as predicted, the continuous incubation of the cells with Genistein for 24hours decreased \% CSR with increasing concentration. Indicating that VLDR chemo-enhanced the effects of Genistein in both cell line types.

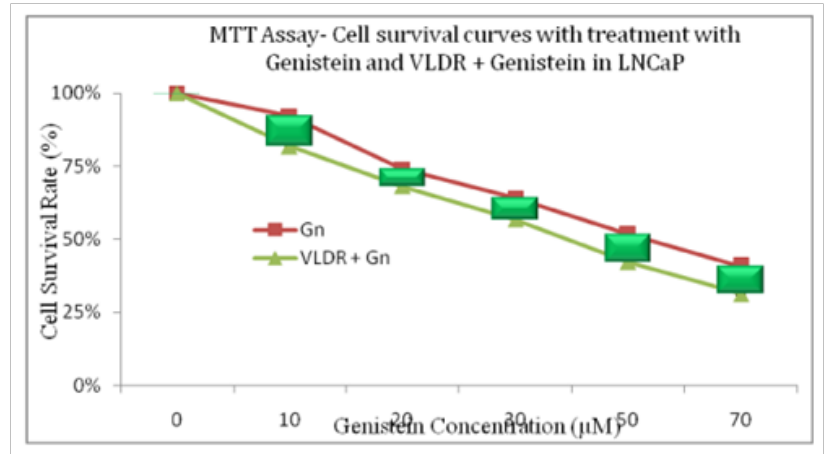

Figure $\mathbf{2 a}$ The \% Cell Survival Rate (CSR; $y$-axis) was plotted against the various doses of genistein ( $x$-axis). The relative difference in cell survival rate curves when Incap were treated with graded doses of genistein isoflavone (gn0-70) alone compared to when pretreatment 0-4 hours with vldr (20mgy/ hr) prior to genistein treatment in Incap cells are shown. Dose-dependent significant decrease $(p<0.05)$ in $\%$ csr was observed. This also correlated with the DGIR or hrs values in Table I.This significant difference $(p<0.05)$ was seen across the various treatment doses (shown by the green bars) when cells were primed with vldr compared to when not primed. Data points represent the means \pm standard deviation of three independent experiments performed in triplicate. Bar $=$ SD. 


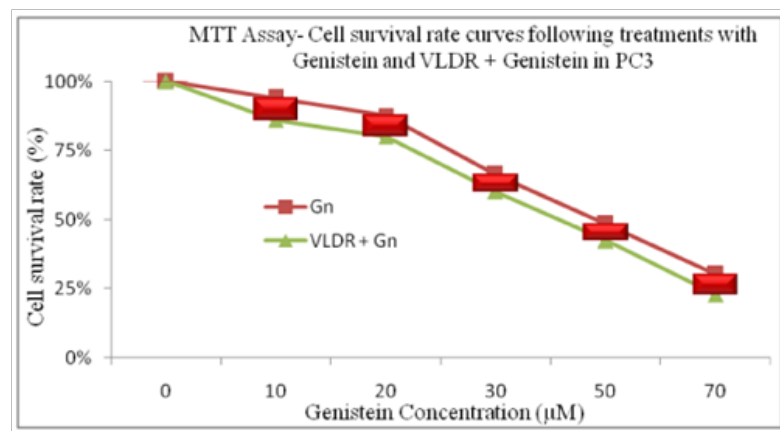

Figure 2b The \% Cell survival rate (CSR; $y$-axis) was plotted against the various doses of genistein $(x$-axis). The relative difference in cell survival rate curves when PC3 were treated with graded doses of genistein Isoflavone (Gn0-70) alone compared to when pretreatment 0-4 hours with VLDR $(20 \mathrm{mGy} / \mathrm{hr})$ prior to genistein treatment in PC3 cells are shown. Dosedependent significant decrease $(P<0.05)$ in \% CSR was observed. This also correlated with the DGIR or HRS values in Table I. This significant difference $(P<0.05)$ was seen across the various treatment doses (shown by the green bars) when cells were primed with VLDR compared to when not primed Data points represent the means \pm standard deviation of three independent experiments performed in triplicate. Bar $=\mathrm{SD}$.

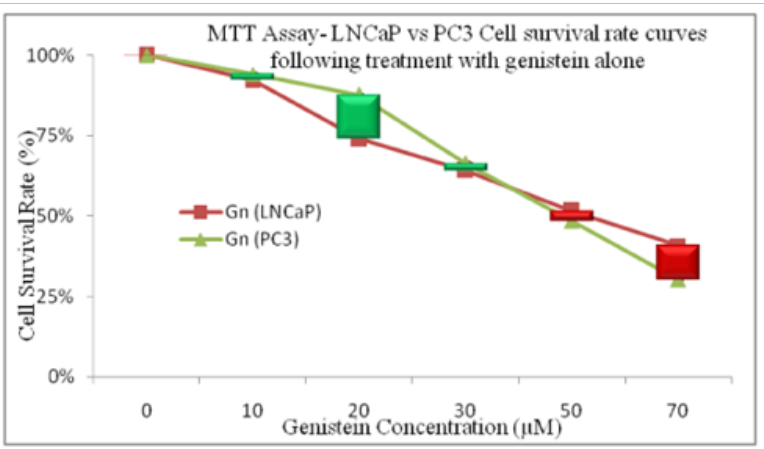

Figure $2 c$ Relative disparity in \% CSR curves between PC 3 and LNCaP cells (shown by the green and red bars) are shown. Dose-dependent significant variations $(P<0.05)$ in \%CSR in both cell lines $(\mathrm{LNCaP}$ and $P C 3)$ were observed after 24 hours of incubation with graded doses of genistein Isoflavone ( $\mathrm{Gn} 0$ 70). At $20 \mu \mathrm{M}, \mathrm{LNCaP}$ cells appear to be more chemo sensitive to genistein treatment compared to $\mathrm{PC} 3$ cells, whereas at $70 \mu \mathrm{M}$, the reverse occurred. Data points represent the means \pm standard deviation of three independent experiments performed in triplicate. $B a r=S D$.

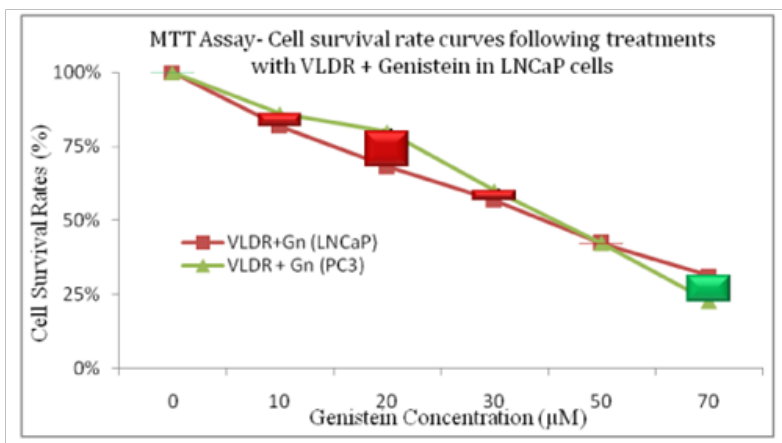

Figure 2d Relative variations in the cell survival rate curves following priming with single doses of VLDR (20mGy/hour) and subsequent treatment with genistein in LNCaP and PC3 are shown. Significant difference $(P<0.05)$ in dose responses at $10-30 \mu \mathrm{M}$ and $70 \mu \mathrm{M}$ between both cell lines LNCaP and PC3 were observed. The dose-dependent difference in treatment-induced cytotoxicity across concentrations of drug is represented by the green and red bars. Data points represent the means \pm standard deviation of three independent experiments performed in triplicate. Bar $=$ SD.

\section{Apoptosis is involved in VLDR-induced chemo enhancement of Genistein in LNCaP cell line}

Treated cells showed dose-dependent degree of cellular cytotoxicity after 24hours incubation (Figure 3). Treated LNCaP cells were observed to be showing series of morphological features (Figure 3C and 3D), such as shrinkage of the cells, nuclear and cytoplasmic condensations, and fragmentation into membrane-bound apoptotic bodies, which are typical hallmarks of apoptotic cell death. Micrograph (Figure 3D) demonstrated that as predicted, a higher percentage of LNCaP cells were undergoing cell death via apoptosis when both treatment modalities were combined compared to when a single treatment with VLDR (Figure 3C) was instituted.
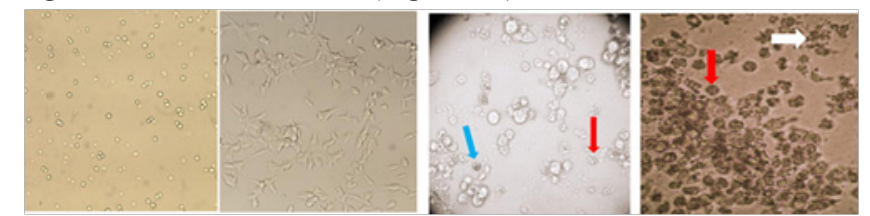

Figure 3 Histomicrographs (100x) in LNCaP cells treated with or without VLDR and / or genistein. (A) LNCaP cells in showing cell morphology at day 0 of incubation. (B) LNCaP cells after 72 hours incubation prior to treatment with VLDR and/or genistein (Gn0-70) showing $>70 \%$ confluence. (C) LNCaP cells showing varying degrees of growth inhibition and cell death, early phase apoptosis (blue arrow) and late phase apoptosis (red arrow) 24 hours after exposure to $20 \mathrm{mGy} / \mathrm{hr}$ (VLDR). (D) LNCaP cells in culture, showing large numbers of late stage apoptotic cells (red arrows) and apoptotic bodies (white arrow) 48 hours after pre exposure toVLDR and treatment $50 \mu \mathrm{M}$ of genistein.

To confirm that apoptosis was induced by VLDR and/or Genistein at concentrations of $10 \mu \mathrm{M}$ and $50 \mu \mathrm{M}$. LNCaP cells were analyzed in the presence of Acridine orange/Ethidium bromide staining (AO/ EB staining). As a control, LNCaP cells were cultured in RPMI 1640 growth media and stained with AO/EB. VLDR and /or Genistein at all concentrations induced apoptosis after 24hours of incubation (Figure 4). Cells that stained green represent viable cells, whereas yellow stained cells represent early apoptotic cells, and reddish or orange stained cells represent late apoptotic cells. $\mathrm{LNCaP}$ cells primed with VLDR and treated with $10 \mu \mathrm{M}$ of Genistein showed changes in cellular morphology, including chromatin condensation, membrane blebbing, and fragmented nuclei (Figure 4B). Similar features were observed in LNCaP cells treated with "VLDR+Gn $(50 \mu \mathrm{M})$ ", but with additional features of late stage apoptotic activity with apoptotic bodies. AO/ EB staining revealed that the morphologic features of apoptotic LNCaP cells were dose-dependent. Similar finding was found for PC3 and even more marked (micrograph not included). At 24hours post treatment, early stage apoptosis appears to be the most dominant cell death in both groups, however few late stage apoptotic cells were observed at "VLDR+Gn $(50 \mu \mathrm{M})$ " (Figure 4).

\section{Time- and dose-dependent induction of adaptive response in VLDR and Genistein treated LNCaP cells}

In order to investigate if adaptive response is dose and/or timedependent, we delayed treatment with Genistein for 4 and 24hours post exposure to single doses of VLDR at $20 \mathrm{mGy} / \mathrm{hr}$. MTT was used to assess the \% CSR, GER ${ }_{\mathrm{AR}}$, DGIR ${ }_{\mathrm{AR}}$ or HRSAR, and ARR. After 24hours, adaptive response was observed, which appear to be dose and time dependent (Table 3). When delayed for 24hours more cells survived compared to when treatment was delayed for just 4hours with graded doses of Genistein. At low doses, adaptive response was minimal whereas at higher doses the adaptive response was more pronounced. The HRSAR and GER ${ }_{A R}$ were observed to decline with increasing concentrations, while the \% CSR and ARR increased across concentration dose-dependently. 

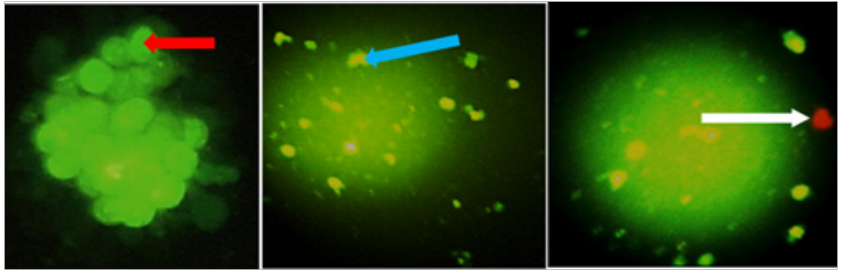

Figure 4 Morphological observation of cell death type with acridine orange/ethidium bromide (AO/EB) staining. LNCaP cells (A) were untreated (Control), (B) were exposed to single dose of VLDR $(20 \mathrm{mGy} / \mathrm{hr})$ with genistein $(\mathrm{I} 0 \mu \mathrm{M}),(\mathrm{C})$ were exposed to high dose concentration of genistein $(50 \mu M)$. Micrographs were taken after incubation for 24 hours post-treatment. Red arrow indicates viable cells; blue arrow indicates early apoptotic cells; white arrow indicates late apoptotic cells. Each experiment was performed in triplicate $(n=3)$ and generated similar morphologic features. Magnification: 200x (4A), 100x (4B \& 4C).
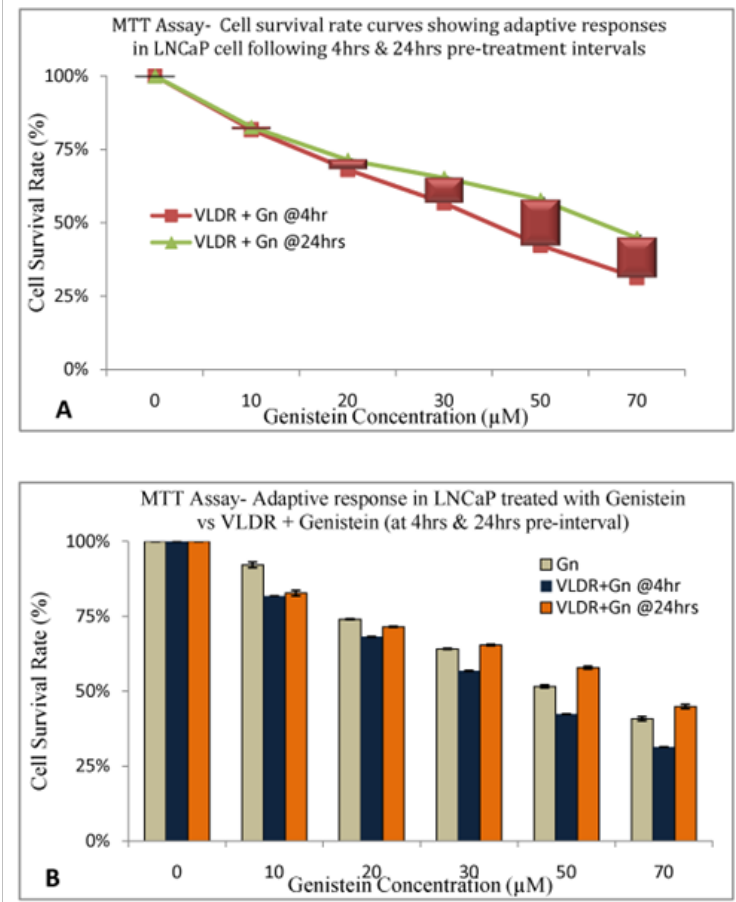

Figure 5 VLDR induced adaptive response due to delayed (24hrs) phototherapeutic treatments after exposure to single doses of VLDR (20mGy/ $\mathrm{hr}$ ) was assessed in $\mathrm{LNCaP}$ cell line by MTT assay.A dose dependent significant increase $(P<0.05)$ in adaptive response to genistein treatment was observed (shown by the red bars representative of \% DGIR in Figure 5A).

$5 A$ showed a significant dose dependent increase $(P<0.05)$ in cell survival rate (\%) due to ability of VLDR to induce adaptive response in the LNCaP cells against the increased cytotoxicity effect of genistein at high doses with 24 treatment intervals. Treatment with low dose of genistein (IO $\mu \mathrm{M})$ at 24 hours interval produces negligible significant adaptive response $(P>0.05)$.

$5 B$ is showing the disparity between dose dependent treatment-induced responses with Gn alone, 'VLDR + Gn' (at 4 hours intervals) and 'VLDR + Gn' (at 24 hours intervals). Data points represent the mean \pm standard deviation (SD) of three independent experiments performed in triplicate.

A dose dependent significant increase $(\mathrm{P}<0.05)$ in adaptive response ratio (ARR) to post-irradiation Genistein treatment was observed (shown by the differences in the height of the red bars in (Figure 5A). It showed a significant dose dependent increase $(\mathrm{P}<0.05)$ in cell survival rate (\%) due to ability of VLDR to induce adaptive response in the $\mathrm{LNCaP}$ cells against the high cytotoxic damaging effects of Genistein at high doses, when delayed for up to 24hours post irradiation. When cells were subsequently treated with a lower dose of Genistein $(10 \mu \mathrm{M})$, no significant adaptive response $(\mathrm{P}>0.05)$ was observed following 24hour delay post irradiation. (Figure 5B) is showing the disparity between adaptive response when cells were treated with Genistein alone, "VLDR + Gn" at 4 hours interval and "VLDR+Gn" at 24hours interval. Data points represent the mean \pm standard deviation (SD) of three independent experiments in triplicate.
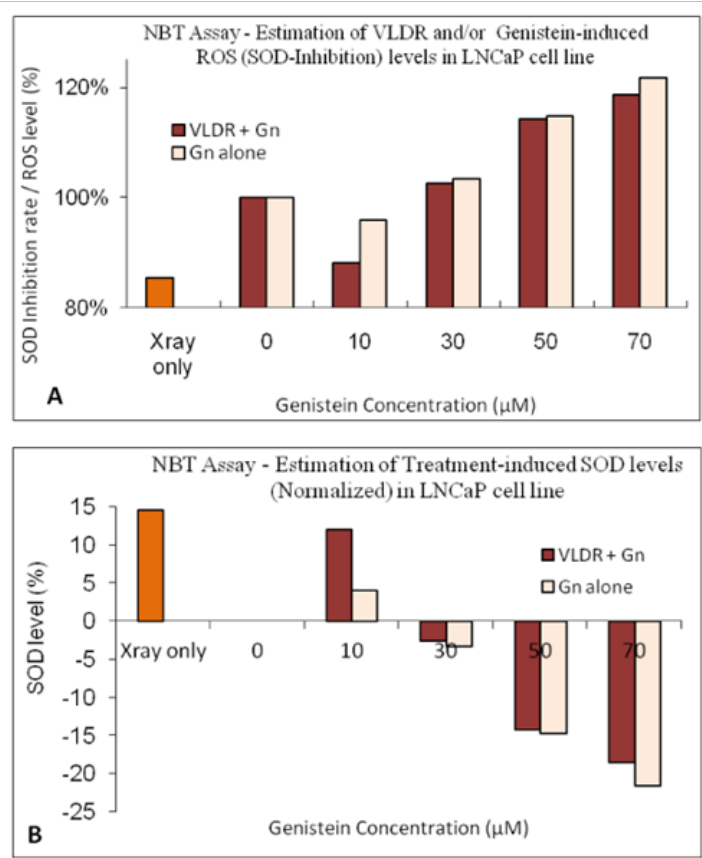

Figure 6 Intracellular levels of ROS (\%) were analyzed using Nitroblue tetrazolium (NBT)-ROS assay as described in the materials and methods. When compared with the control group, all treatment regimens had elevated levels of ROS, except at low dose of genistein $(10 \mu \mathrm{M})$ orVLDR alone, in which a significant drop $(P<0.05)$ in levels of ROS $(-4.06 \%$ and $-14.55 \%$ respectively $)$ were observed. By combining VLDR with low dose genistein $(10 \mu \mathrm{M})$, a marked drop in the levels of ROS was observed (-1 I.94\%). Significant dose dependent increase in the levels of ROS (superoxide ions) was observed in the combined treatments, but not as high as when treated alone with genistein (Figure $6 \mathrm{~A})$. Intracellular \% SOD levels were analyzed as described in the materials and methods. The \% SOD level was significantly higher $(P<0.05)$ with VLDR $(+14.55 \%$, when normalized) and also with low dose $(10 \mu \mathrm{M})$ of genistein $(+4.06 \%)$. By combining VLDR with low dose genistein $(10 \mu \mathrm{M})$, a marked increase $(P<0.05)$ in the SOD level was observed $(+\mid I .94 \%)$, higher than the control and treatment with Genistein alone (Figure 6B). Data points represent the mean \pm Standard Deviation $(\mathrm{SD})$ of three independent experiments performed in triplicate.

These results indicate that when combining these two therapies, time interval between treatments is very important as too much delay could lead to a higher adaptive response which could forfeit the therapeutic intentions of this protocol. We suggest that following VLDR exposure cancer cells should be treated with drugs between 0-4hours to maximize the HRS phenomenon. On the other hand, the adaptive response could also help protect the normal cells from the cytotoxic effect of high dose Genistein Isoflavone.

\section{VLDR and/or Genistein modulates the intracellular levels of ROS and SOD in LNCaP cells}

Intracellular \% ROS levels were analyzed using Nitro blue Tetrazolium (NBT)-ROS assay based on the principle of SOD 
inhibition. NBT reduction is used as an indicator of superoxide ion (free radical) production. When compared with the control group, all treatment regimens had elevated ROS levels except at low dose of Genistein $(10 \mu \mathrm{M})$ and VLDR alone, in which a significant drop $(\mathrm{P}<0.05)$ in ROS levels $(-4.06 \%$ and $-14.55 \%$ respectively) were observed. By combining VLDR with low dose Genistein $(10 \mu \mathrm{M})$, a marked drop in the ROS level was observed (-11.94\%). Significant dose dependent increase in the ROS (Superoxide radicals) levels was also observed in the combined treatment, but not as high as with Genistein alone (Figure 6A).

Intracellular \% SOD levels were also analyzed as described in the materials and methods. The obtained results indicated that decrease in levels of \% SOD correlated with increase in the doses administered; implying that decrease in intracellular SOD for Genistein is dosedependent. Compared with the control group, all treatment regimens had dose dependent reduced levels of SOD due to Genistein-induced increase in superoxide production at high doses. The \% SOD level was significantly higher $(\mathrm{P}<0.05)$ with VLDR $(+14.55 \%$, when normalized) and also with low dose $(10 \mu \mathrm{M})$ of Genistein $(+4.06 \%)$. By combining VLDR with low dose Genistein $(10 \mu \mathrm{M})$, a marked increase $(\mathrm{P}<0.05)$ in the SOD level was observed $(+11.94 \%)$, higher than the control and treatment with Genistein alone (Figure 6B).
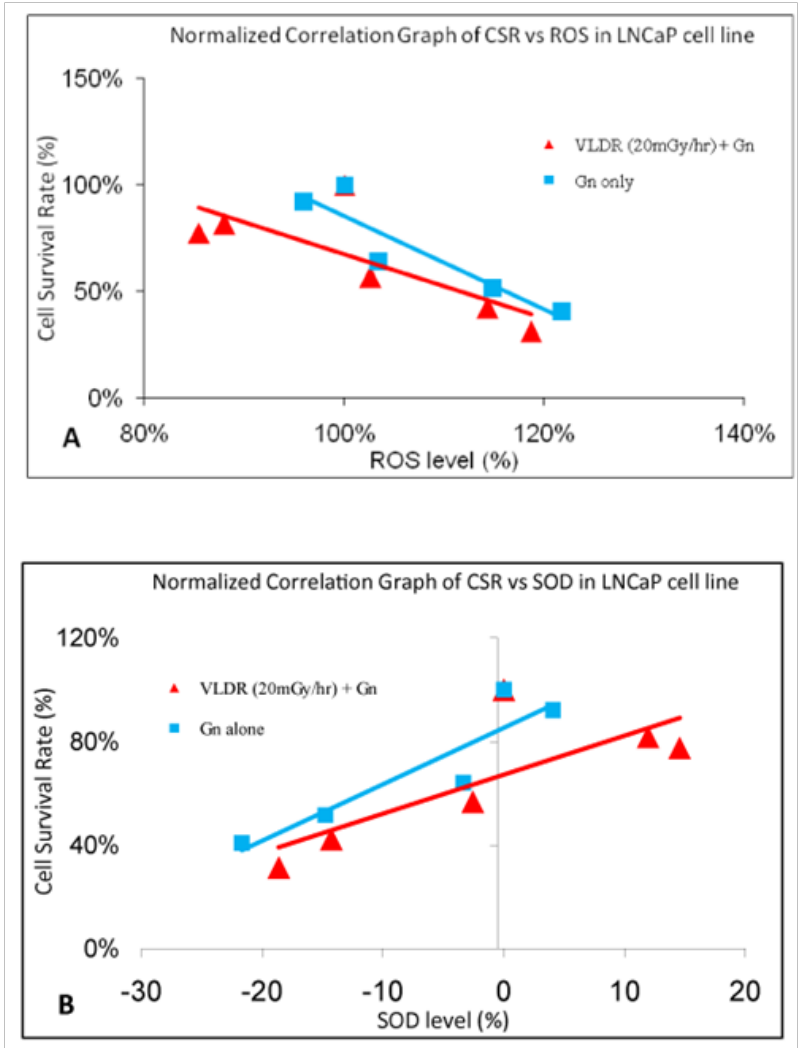

Figure 7 Correlation graphs of \% Cell survival rate (CSR) relative to SOD and ROS in LNCaP cells were plotted. Covariance of CSR and ROS level shows negative correlation between the two parameters ((VLDR+ Gn: $y=$ $\left.-1.5072 x+2.1796 ; R^{2}=0.6048\right)\left(G n\right.$ alone: $\left.y=-2.18 x+3.0335 ; R^{2}=0.8385\right)$ while covariance of CSR and SOD show positive correlation ((VLDR+Gn: $y=$ $\left.0.0151 x+0.6724 ; R^{2}=0.6048\right)\left(G n\right.$ alone: $\left.y=0.0218 x+0.8535 ; R^{2}=0.8385\right)$. The line of best fit for each treatment protocol of VLDR and genistein combined and genistein only was drawn to determine the correlation.

Correlation graphs were constructed to determine the relationship between \% CSR and ROS or SOD (Figure 7A and 7B) in treated $\mathrm{LNCaP}$ cell line. Covariance of CSR and ROS levels showed negative correlation (VLDR+Gn: $\mathrm{R}^{2}=0.8385$; Gn alone: $\left.\mathrm{R}^{2}=0.6048\right)$, while covariance of CSR and SOD levels showed positive correlation between both parameters (VLDR+Gn: $\mathrm{R}^{2}=0.8385$; Gn alone: $\mathrm{R}^{2}=$ 0.6048). The line of best fit for each treatment protocol was drawn to determine their correlation.

\section{Discussion}

MTT assay has been used by many investigators to measure chemo sensitivity in human tumor cell lines. ${ }^{12,18}$ Its use in investigating the response of cells to ionizing radiation has received fewer considerations. This is because clonogenic assay is the most reliable and best choice for most investigators to assess traditionally radiation cell survival rate..$^{53}$ However, clonogenic assays have some limitations, which include; long days for colonies formation, making it inapplicable when rapid assessment of cell survival rate is needed; and also, inaccessibility to acute response to high doses and/or very low doses of radiation. Furthermore, clonogenic assay cannot be used for non-colony forming cells. MTT assay has been validated as an alternative to the clonogenic assay, to assess the response of prostate cancer cells, to very low doses of radiation and combination treatments. ${ }^{54,55}$ Our results demonstrate that single doses of very low radiation are potent chemo enhancers or chemo sensitizers of Genistein Isoflavone in human prostate cancer cells; evidence indicating that mechanisms involved in modulation of cellular oxidative stress may play certain roles in increasing radio sensitization (HRS) and chemo sensitization of prostate cancer cell lines by VLDR. Cancer cells are known to produce high levels of ROS and survive under physiologic oxidative stress. ${ }^{56}$ For these cancer cells to survive, they must maintain a balanced redox signals for cellular proliferation. ${ }^{57}$ However, any pathologic change in the redox signaling system, such as overproduction or underproduction of ROS beyond the physiologic state may results in a significant increase in pathologic oxidative stress, which leads to growth inhibition and/or cell death. ${ }^{56,58}$ Prostate cancer is known to be an age dependent disease that can be caused by increased oxidative stress in older men. ${ }^{59}$

An emerging chemopreventive approach, involving the adequate intake of dietary constituents, including phytochemical to reverse or inhibit the process of carcinogenesis, ${ }^{11,60,61}$ have shown great potential in preventing the occurrence of cancer and other chronic diseases that result from oxidative stress induced by free radicals. ${ }^{8,9,62}$ Interestingly, some studies have indicated that about $30 \%$ of US men between the ages of 20 and 40years have microscopic sized cancers in their prostate. ${ }^{63,64}$ Thus, chemopreventive interventions with combination therapies-drugs, diets or low dose radiation that slow down or inhibit the growth and progression of these small tumors are potentially very effective in reducing the burden of prostate cancers, particularly if these treatments also prevent the de novo development of new prostatic malignancies. ${ }^{65}$ Like most flavonoid, Genistein is known to exhibit dual redox activity at different treatment conditions. Genistein have been demonstrated in prostate cancer cells to have anti-cancer activities in both low and high dose concentrations against both androgen-dependent (LNCaP) and androgen-independent (PC3) human prostate carcinoma cell lines. ${ }^{7,12,18}$ More studies revealed that Genistein can also prevent lipid peroxidation in cell-free and cellular systems. ${ }^{16,66}$

At high or low dose concentrations, they are known to exhibit prooxidant and antioxidant activities respectively). Both mechanisms have been indicated to increase the antitumor activity of Genistein 7,67. In the current study, at low concentration $(10 \mu \mathrm{M})$ of Genistein, we observed reductions in the intracellular ROS generation and increase in SOD, whereas at high concentrations $(>50 \mu \mathrm{M})$ of 
Genistein treatments, an increase in ROS production was observed. Interestingly, this is consistent with most published reports on anticancer properties of Genistein and other polyphenolic phytochemical compounds in modulating ROS production and activity. ${ }^{7,16,68}$ When cells were primed with single doses of very low radiation (VLDR), especially after treatment with Genistein at lower doses, a further statistical significant decrease $(\mathrm{P}<0.05)$ in the intracellular ROS level was observed after 24 hours incubation post-treatment. VLDR alone was also found to induce a marked significant decrease $(\mathrm{P}<0.05)$ in the ROS level and cause the significant increase $(\mathrm{P}<0.05)$ in antioxidant enzymes such as superoxide dismutase (SOD). Hence, VLDR and/or low doses of Genistein possibly activate chemopreventive activities in prostate cancer cells by enhancing the antioxidant enzyme systems.

Hyper-radio sensitivity (HRS) describes the extreme sensitivity of cells to low doses of low-linear energy transfer (low-LET) radiation. This phenomenon can be attributed to apoptosis or growth inhibition after dose-dependent damage detection processes and the transition of low dose HRS have been demonstrated to be regulated by the 'early' G2/M checkpoint. ${ }^{69}$ Meanwhile another study has shown that Genistein can increase the radiosensivity of prostate cancer cells. ${ }^{70}$ The invention of pyroelectric X-ray generator technology using pyroelectric crystals as an $\mathrm{X}$-ray source has provided an avenue for scientist to develop ultraportable, low-power X-ray sources for use in research labs for imaging, materials analysis, and other applications. ${ }^{41,42,44}$ High doses of low LET X-rays are known to cause DNA double strand breaks that lead to cell damage and death. Effects at low doses are usually difficult to quantify as many believes it may be negligible at low doses or low dose rate of photon irradiation. ${ }^{48}$ Most studies condemning the beneficial effect of low dose radiation had been a product of extrapolation from high doses and from atomic bomb patients, which may not be truly representative of events in this range of radiation exposure. ${ }^{71}$

Revolutionary studies done by some investigators have expanded the knowledge bank of cellular and molecular events at low dose or dose rate radiation exposure, in relations to characteristic phenomena such as hormesis, low-dose hyper-radio sensitivity (LD-HRS), genomic instability, adaptive responses, bystander effects, and radio-resistance with subsequent higher doses of radiation in some mammalian cells.$^{35}$ Low doses of radiation have been found to exert anti-oxidant properties by modulating the usual ROS favored redox signaling for carcinogenesis, thereby leading to growth inhibition, apoptosis and other forms of cell damage or deaths. ${ }^{72,73}$

The rapid development in cell and molecular biology has increased the understanding of programmed cell death (apoptosis). ${ }^{74}$ Cell killing through apoptosis is an early endpoint that could be easily measured both in cells that had energy deposited in them and in their neighbors. ${ }^{75,76}$ Elimination of cells by apoptosis can potentially result in a decrease in damaged cells or transformed cells; resulting in a protective effect. ${ }^{77}$ This observation is consistent with the results of our study. The overall data indicate that prostate cancer cells are susceptible to death by apoptosis in response to VLDR and Genistein. Most of the cellular deaths observed in all the treatment groups were apoptosis, as revealed by the Acridine orange/ Ethidium bromide fluorescence assay, consistent with previous studies on Genistein. ${ }^{7,12,18}$ The data also demonstrated the synergism or potential benefit of VLDR and Genistein to induce cytotoxicity, growth inhibition and ultimately cell death by apoptosis. Our data also suggest that an up regulation of anti-oxidant enzymes (SOD) and a drop in ROS (superoxide ions) at very low dose of radiation $(20 \mathrm{mGy} / \mathrm{hr})$ and $/$ or low dose concentrations of Genistein $(10 \mu \mathrm{M})$ exposure may be mechanistic in the cytotoxic effects, and the HRS and apoptotic cell deaths. The detailed mechanism of growth inhibition and cytotoxicity at combined VLDR and high doses of Genistein is under further investigation.

Adaptive response indicates a survival advantage by cells after exposure to very low doses of ionizing radiation 4-24hours prior to a highly challenging dose of cell damaging agents. ${ }^{78-80}$ Previous studies have demonstrated that adaptive response to a subsequent high dose challenge of cytotoxic drug ${ }^{81}$ or ionizing radiation ${ }^{82,83}$ can be induced by pretreatment with very low doses of ionizing radiation..$^{78,84,85}$ Some investigators have reported variations in adaptive responses of different cells following post-VLDR intervals ranging from 4-24hours between priming and subsequent exposure to a higher dose of drug or radiation. In the current study involving priming with VLDR and subsequent Genistein treatments, we were able to demonstrate a time and dose dependent adaptive response in LNCaP prostate cancer cells by experimenting with intervals of the lower limit (4 hours) and the upper limit (24hours). ${ }^{78,81,85}$

This study has pioneered the use of pyroelectrically generated very low doses of X-ray radiation (generated from a non-radioactive source-Pyroelectric crystal) in cancer therapy. At the $20 \mathrm{mGy} /$ hour absorbed dose used for this study, the pyroelectric X-ray generator was able to generate low LET X-rays at a dose rate of $0.3 \mathrm{mGy} / \mathrm{min}$ similar to "pulse reduced dose rate radiotherapy-when thermally cycled. The overall data substantiate the potential chemopreventive/ chemotherapeutic efficacy of Genistein combination with pyroelectrically generated radiation in human prostate cancer cell lines. The study presents a novel approach to the enhancement/ augmentation of the phototherapeutic activities of Genistein Isoflavone in prostate cancer cells. Low dose radiation properties such as hyperradio sensitivity (HRS) and adaptive responses were also observed in this study. It is therefore conceivable that conducting more in-depth studies to enhance HRS and to define adaptive responses in prostate cancer cell lines could augment the potential benefits of radiationphytochemical combination regimen, to manage prostate cancer.

\section{Conclusion}

In conclusion, our study demonstrates that hormone dependent prostate cancer cells exposed to single doses of very low dose radiation (VLDR) are more radiosensitive than hormone independent prostate cancer cells through a moderate elevation of the HRS. We also observed an increase in adaptive response in the prostate cancer cells especially LNCaP cells, when treatment with high doses of Genistein Isoflavone was delayed up to 24 hours following priming with VLDR. This infers that time and dose ranges are major factors to consider when combining both therapies. To the best of our knowledge, this is the first time that pyroelectrically generated X-rays are used to induce and/or investigate cellular responses to VLDR in prostate cancer cells. It is also the first study to investigate the synergistic and/or enhancing effects of very low dose radiation (VLDR) therapy on phytotherapeutic efficacy of Genistein Isoflavone in any human tumor in vitro. The present study provides a rationale for further studies in radiation-phytochemical combination regimen.

\section{Acknowledgments}

None.

\section{Conflicts of interest}

Authors declare there are no conflicts of interest. 


\section{References}

1. Cancer facts and figures. American Cancer Soc Inc: Atlanta, USA; 2014. 1-68 p.

2. Siegel R, Ma J, Zou Z, et al. Cancer statistics. CA Cancer J Clin. 2014;64(1):9-29.

3. Chou R, Dana T, Bougatsos C, et al. Treatments for localized prostate cancer: systematic review to update the 2002 U.S. preventive services task force recommendation. Evidence Synthesis no.91. Rockville, MD: Agency for Healthcare Research and Quality; 2011.

4. Welch HG, Albertsen PC. Prostate cancer diagnosis and treatment after the introduction of prostate- specific antigen screening: 1986-2005. $J$ Natl Cancer Inst. 2009;101(19):1325-1329.

5. Zincke H, Bergstralh EJ, Blute ML, et al. Radical prostatectomy for clinically localized prostate cancer: long-term results of 1,143 patients from a single institution. J Clin Oncol. 1994;12:2254-2263.

6. Adolfsson J, Steineck G, Whitmore WF. Recent results of management of palpable clinically localized prostate cancer. Cancer. $1993 ; 72(2): 310-322$.

7. Hormann V, Kumi-Diaka J, Durity M, et al. Anticancer activities of genistein-topotecan combination in prostate cancer cells. J Cell Mol Med. 2012;16(11):2631-2636.

8. Abdulla M, Gruber P. Role of diet modification in cancer prevention Biofactors. 2000;12(1-4):45-51.

9. Agarwal C, Sharma Y, Agarwal R. Anticarcinogenic effect of a polyphenolic fraction isolated from grape seeds in human prostate carcinoma DU145 cells: modulation of mitogenic signaling and cellcycle regulators and induction of G1 arrest and apoptosis. Mol Carcinog. 2000;28(3):129-138.

10. Giovannucci E, Rimm EB, Colditz GA, et al. A prospective study of dietary fat and risk of prostate cancer. J Natl Cancer Inst. 1993;85(19):1571-1579.

11. Clinton SK, Giovannucci E. Diet, nutrition and prostate cancer. Annu Rev Nutr. 1998;18:413-440.

12. Kumi Diaka J, Saddler Shawnette S, Aller A, et al. Potential mechanism of phytochemical-induced apoptosis in human prostate adenocarcinoma cells: therapeutic synergy of genistein and B-lapachone combination treatment. Cancer Cell Int. 2004;4(1):5.

13. Tham DM, Gardner CD, Haskell WL. Clinical review 97: potential health benefits of dietary phytoestrogens: a review of the clinical, epidemiological, and mechanistic evidence. J Clin Endocrinol Metab. 1998;83(7):2223-2235

14. Alhasan SA, Pietrasczkiwicz H, Alonso MD, et al. Genistein-induced cell cycle arrest and apoptosis in a head and neck squamous cell carcinoma cell line. Nutr Cancer. 1999;34(1):12-19.

15. Buckley AR, Buckley DJ, Gout PW, et al. Inhibition by genistein of prolactin-induced nb2 lymphoma cell mitogenesis. Mol Cell Endocrinol. 1993;98(1):17-25.

16. Chen WF, Huang $\mathrm{MH}$, Tzang $\mathrm{CH}$, et al. Inhibitory actions of genistein in human breast cancer (MCF-7) cells. Biochim Biophys Acta. 2003;1638(2):187-196.

17. Constantinou A, Kiguchi K, Huberman E. Induction of differentiation and DNA strand breakage in human HL-60 and K-562 leukemia cells by genistein. Cancer Res. 1990;50(9):2618-2624.

18. Kumi-Diaka J. Chemosensitivity of human prostate cancer cells PC3 and Lncap to Genistein Isoflavone and B-Lapachone. Bio Cell. 2002; 4(1):37-44

19. LiY, Upadhyay S, Bhuiyan M, et al. Induction of apoptosis in breast cancer cells MDA-MB-231 by Genistein. Oncogene. 1999;18(20):3166-3172.
20. Merchant K, Kumi-Diaka J, Rathinavelu A, et al. Genistein modulation of immune-associated genes in lncap prostate cancer cell line. The Open Prostate Cancer Journal. 2012;5:1-7.

21. Peterson G, Barnes S. Genistein inhibits both estrogen and growth factor-stimulated proliferation of human breast cancer cells. Cell Growth Differ. 1996;7(10):1345-1351.

22. Spinozzi F, Pagliacci MC, Migliorati $G$, et al. The natural tyrosine kinase inhibitor genistein produces cell cycle arrest and apoptosis in Jurkat T-leukemia cells. Leuk Res. 1994;18(6):431-439.

23. Tophkhane $\mathrm{C}$, Yang $\mathrm{S}$, Bales W, et al. Bcl-2 over expression sensitizes MCF-7 cells to genistein by multiple mechanisms. Int $J$ Oncol. 2007;31(4):867-874.

24. Jagadeesh S, Kyo S, Banerjee PP. Genistein represses telomerase activity via both transcriptional and posttranslational mechanisms in human prostate cancer cells. Cancer Res. 2006;66(4):2107-2115.

25. Li Y, Sarkar FH. Inhibition of nuclear factor kappab activation in PC3 cells by genistein is mediated via akt signaling pathway. Clin Cancer Res. 2002;8(7):2369-2377.

26. Li Y, Che M, Bhagat S, Ellis KL, et al. Regulation of gene expression and inhibition of experimental prostate cancer bone metastasis by dietary genistein. Neoplasia. 2004;6(4):354-363.

27. Li Y, Bhuiyan M, Sarkar FH. Induction of apoptosis and inhibition of C-Erbb-2 in MDA-MB-435 cells by genistein. Int $J$ Oncol. 1999;15(3):525-533.

28. Zhou JR, Gugger ET, Tanaka T, et al. Soybean phytochemicals inhibit the growth of transplantable human prostate carcinoma and tumor angiogenesis in mice. $J$ Nutr. 1999;129(9):1628-1635.

29. Dixon RA, Ferreira D. Genistein. Phytochemistry. 2002;60(3):205-211.

30. BEIR VII. Health risks from exposure to low levels of ionizing radiation. The National Academies Press: Washington, USA; 2006.

31. Feinendegen LE, Bond VP, Sondhaus CA. The dual response to low dose irradiation: Induction vs prevention of DNA damage biological effects of low dose radiation. In: Yamada T, et al. (Eds). Excerpta Medica. International Congress Series 12-11. Elsevier, Amsterdam, London, New York, Oxford, Paris, Shannon, Tokyo; 2000. 3-17 p.

32. Tubiana M, Feinendegen LE, Yang C, et al. The linear no-threshold relationship is inconsistent with radiation biologic and experimenta data. Radiology. 2009;251(1):13-22.

33. Feinendegen LE, Pollycove M, Neumann RD. Whole body responses to low-level radiation exposure. New concepts in mammalian radiobiology. Experim Hematol. 2007;35(4 Suppl 1):37-46.

34. Azzam EI, de Toledo SM, Raaphorst GP, et al. Low-dose ionizing radiation decreases the frequency of neoplastic transformation to a level below the spontaneous rate in $\mathrm{C} 3 \mathrm{H}$ 10T1/2 cells. Radiat Res. 1996;146(4):369-373.

35. Marples B, Collins SJ. Low dose hypersensitivity: past, present and future. Int J Radiat Oncol Biol Phys. 2008;70(5):1310-1318.

36. Tallman R. Accelerator X-Ray Sources. Wiley-VCH; 2006.

37. Bizek H. The advanced photon source list of parameters. Argonne Nat Lab: Lemont, IL; 1996.

38. Pfeiffer F. Hard X-rays phase tomography with low- brilliance sources. Phys Rev Let. 2007;98(10):108-114.

39. Benwell A, Kovaleski S, Kemp M. A resonantly driven piezoelectric transformer for high voltage generation. In Proc IEEE Intl Power Modula High Volt Conf; 2008. 113-116 p.

40. Hird J.Atriboelectric x-ray source. Apple Phys Lot. 2001;98(13):501-503. 
41. Brownridge JD. Pyroelectric X-ray generator. Nature. 1992;358:287-288.

42. Geuther JA, Danon Y. High-energy x-ray production with pyroelectric crystals. J Appl Phys. 2005;97:104916.

43. Gall B, Kowalski SD, VanGordon JA, et al. Investigation of the piezoelectric effect as means to generate x-rays. IEEE, Transactions on Plasma Science. 2013;41(1):106-111.

44. Brownridge JD, Raboy S. Investigations of pyroelectric generation of X-rays. J Appl Phys. 1999;86:640-647.

45. Kumar R, Verma V, Jain A, et al. Synergistic chemoprotective mechanisms of dietary phytoestrogens in a select combination against prostate cancer. J Nutr Biochem. 2010;22(8):723-731.

46. Cai L, Feinendegen LE, Ikusshima T, et al. Special issue: adaptive response induced by low levels of radiation. BELLE Newsletter. 1999; 7(3):2-31.

47. Day TK, Zeng G, Hooker AM, et al. Extremely low priming doses of $\mathrm{X}$ radiation induce an adaptive response for chromosomal inversions in Pkz1 mouse prostate. Radiat Res. 2006;166(5):757-766.

48. Luckey TD. Physiological benefits from low levels of ionizing radiation. Health Phys. 1982;43(6):771-789.

49. Chou TC, Chou JH. Computerized indexing of drug combinations: prediction of synergism and antagonism of more than two drugs by polygonogram; 1998.

50. Short S, Mayes C, Woodcock M, et al. Low dose hypersensitivity in the T98g human glioblastoma cell line. Int $J$ Radiat Biol. 1998;75(7):847-855.

51. Dominguez-Rodriguez JR, Gomez-Contreras PC, Hernandez-Flores $\mathrm{G}$, et al. In vivo inhibition by antioxidants of adriamycin-induced apoptosis in murine peritoneal macrophages. Anticancer Res. 2001;21(3B):1869-1872.

52. Zhao Y, Kiningham KK, Lin SM, et al. Overexpression of MnSOD protects murine fibrosarcoma cells (FSa-II) from apoptosis and promotes a differentiation program upon treatment with 5-azacytidine: involvement of MAPK and NFkappaB pathways. Antioxid Redox Signal. 2001;3(3):375-386.

53. Franken NA, Rodermond HM, Stap J, et al. Clonogenic assay of cells in vitro. Nat Protoc. 2006;1(5):2315-2319.

54. Price P, McMillan TJ. Use of the tetrazolium assay in measuring the response of human tumor cells to ionizing radiation. Cancer Res. 1990;50(5):1392-1396.

55. Williams JR, Zhang Y, Zhou H, et al. Overview of radiosensitivity of human tumor cells to low-dose-rate irradiation. Int J Radiat Oncol Biol Phys. 2008;72(3):909-917.

56. Finkel T, Holbrook NJ. Oxidants, oxidative stress and the biology of aging. Nature. 2000;408(6809):239-247

57. Martin KR, Barrett JC. Reactive oxygen species as double-edged swords in cellular processes: low-dose cell signaling versus high-dose toxicity. Hum Exp Toxicol. 2002;21(2):71-75.

58. Chandra J, Samali A, Orrenius S. Triggering and modulation of apoptosis by oxidative stress. Free Radic Biol Med. 2000;29(3-4):323-333.

59. Ferlay J, Soerjomataram I, Ervik M, et al. GLOBOCAN 2012 v1.0, cancer incidence and mortality worldwide: IARC cancer base no. 11 [Internet]. Lyon, France: International Agency for Research on Cancer. 2013.

60. Sarkar FH, Li Y. Indole-3-carbinol and prostate cancer. J Nutr. 2004;134(12 Suppl):3493S-3498S.

61. Tsuda H, Ohshima Y, Nomoto H, et al. Cancer prevention by natural compounds. Drug Metab Pharmacokinet. 2004;19(4):245-263.
62. Fleshner NE, Klotz LH. Diet, androgens, oxidative stress and prostate cancer susceptibility. Cancer Metastasis Rev. 1998;17(4):325-330.

63. Sakr WA, Haas GP, Cassin BF, et al. The frequency of carcinoma and intraepithelial neoplasia of the prostate in young male patients. $J$ Urol. 1993;150(2 Pt 1):379-385.

64. Sakr WA, Grignon DJ, Haas GP, et al. Age and racial distribution of prostatic intraepithelial neoplasia. Eur Urol. 1996;30(2):138-144.

65. Kelloff GJ, Lieberman R, Steele VE, et al. Chemoprevention of prostate cancer: concepts and strategies. Eur Urol. 1999;35(5-6):342-350.

66. Ho SC, Woo JL, Leung SS, et al. Intake of soy products is associated with better plasma lipid profiles in the Hong Kong Chinese population. J Nutr. 2000;130(10):2590-2593.

67. Li D, Yee JA, McGuire MH, Murphy PA, et al. Soybean isoflavones reduce experimental metastasis in mice. J Nutr. 1999;129(5):1075-1078.

68. Galati G, Sabzevari O, Wilson JX, et al. Prooxidant activity and cellular effects of the phenoxyl radicals of dietary flavonoids and other polyphenolics. Toxicology. 2002;177(1):91-104.

69. Liu SZ, Zhang YC, Mu Y, et al. Thymocyte apoptosis in response to low-dose radiation. Mutat Res. 1996;358(2):185-191.

70. Ejima Y, Yan S, Sasaki R, et al. Combination of genistein with ionizing radiation on surviving fraction, apoptosis and cell cycle alterations on DU-145 prostate cancer cells. International Journal of Radiation Oncology Biology Physics. 2003;57(2):S353

71. Heidenreich WF, Paretzke HG, Jacob P. No evidence for increased tumour rates below $200 \mathrm{Msv}$ in atomic bomb survivors.\&nbsp;Radiat Environ Biophys. 1997;36(3):205-207.

72. Kojima S, Matsuki O, Nomura T, et al. Elevation of antioxidant potency in the brain of mice by low-dose gamma-ray irradiation and its effect on 1-methyl-4-phenyl-1, 2, 3, 6-tetrahydropyridine (MPTP)-induced brain damage. Free Radio Biol Med. 1999;26(3-4):388-395.

73. Yamaoka K, Mori S, Nomura T, et al. Elevation of antioxidant potency in mice brain by low-dose x-ray irradiation and its effect on Fe-NTA-induced brain damage. Physiol Chem Phys Med NMR. 2002;34(2):119-132.

74. Hu W, Kavanagh JJ. Anticancer therapy targeting the apoptotic pathway. Lancet Oncol. 2003;4(12):721-729.

75. Kroemer G. Mitochondrial control of apoptosis: an overview. Biochem Soc Symp. 1999;66:1-15.

76. Pollycove M, Feinendegen LE. Biologic response to low doses of ionizing radiation: Detriment versus hormesis. Part 2: Dose responses of organisms.\&nbsp;J Nucl Med. 2001;42(9):26N-32N,37N.

77. Evan GI, Vousden KH. Proliferation, cell cycle and apoptosis in cancer. Nature. 2001;411(6835):342-348.

78. Bosi A, Olivieri G. Variability of the adaptive response to ionizing radiation in humans. Mutat Res. 1989;211(1):13-17.

79. Shadley JD, Wolff S. Very low doses of x-ray can cause human lymphocytes to become less susceptible to ionizing radiation. Mutagenesis. 1987;2(2):95-96.

80. Boothman DA, Meyers M, Odegaard E, et al. Altered G1 checkpoint control determines adaptive survival responses to ionizing radiation. Mutat Res. 1996;358(2):143-153.

81. Samson L, Schwartz JL. Evidence for an adaptive DNA repair pathway in $\mathrm{CHO}$ and human skin fibroblast cell lines. Nature. 1980;287(5785):861-863.

82. Wolff S, Wiencke JK, Afzal V, et al. The adaptive response of human lymphocytes to very low doses of ionizing radiation: a case of induced chromosomal repair with the induction of specific proteins. In: Baverstok KM, Stather JW (Eds.), Low dose radiation: biological bases of risk assessment. Taylor \&amp; Francis: London, UK; 1989. 620 p. 
83. Ishii K, Watanabe M. Participation of gap-junctional cell communication on the adaptive response in human cells induced by low dose of $\mathrm{x}$-rays. Int J Radiat Biol. 1996;69(3):291-299.

84. Azzam EI, Raaphors GP, Mitchel RE. Radiation induced adaptive response for protection against micronucleus formation and neoplastic transformation in $\mathrm{C} 3 \mathrm{H}$ 10T/1/2 mouse embryo cells. Radiat Res. 1994;138(1Suppl):S28-S31
85. Seong JS, Suh CO, Kim GE. Adaptive response to ionizing radiation induced by low doses of gamma rays in human cell lines. Int $J$ Radiat Oncol Biol Phys. 1995;33(4):869-874. 